\title{
Determination of Ammonia, Nitrate and Nitrite concentrations in Marine Water samples with cultured marine ornamental fish water sample analysis
}

\author{
T. Manikandarajan*, K. Ramamoorthy, S. Shanmugasundaram, A. Eswar, \\ K. Kathirvel, G. Sankar \\ Centre of Advanced Study in Marine Biology, Faculty of Marine Sciences, \\ Annamalai University, Parangipettai - 608 502, Tamil Nadu, India. \\ E-mail address: thillairaja01@gmail.com.
}

Keywords: Marine water sample, Ammonia, Nitrite, Nitrate, Dissolved oxygen, Temperature, Salinity and $\mathrm{pH}$

\begin{abstract}
The present studies were concentration of ammonia, nitrite, nitrate, dissolved oxygen, temperature, salinity and $\mathrm{pH}$. For seven physicochemical parameters were determined in marine water samples along with marine ornamental fish water sources from CAS in marine biology laboratory conditions at Parangipettai. Water sample have been studied at a marine water sources. The study concentrations of parameters like ammonia, nitrite, nitrate, dissolved oxygen, temperature, salinity, and $\mathrm{pH}$. And physicochemical parameters have been calculated. The data showed the difference of the investigated parameters in samples as follows; Concentration of water quality parameters like ammonia was maximum level above $1.158 \mu \mathrm{mol}^{-} 1$, nitrite was ranging from 0.811 to $0.922 \mu \mathrm{mol}^{-} 1$, nitrate was range maximum level above $4.84 \mu \mathrm{mol}^{-} 1$, dissolved oxygen content was maximum level above $2.4 \mathrm{mg}^{-}$, temperature was ranging from 32.3 to $100{ }^{\circ} \mathrm{C}$, salinity values ranging from 0 to $36 \mathrm{ppt}$ and $\mathrm{pH}$ was ranging from 6.5 to 8.0. During the study period of from July 2013 to June 2014 we investigated concentration of seven physicochemical parameters value Marine water samples with cultured fish species in presence of water from CAS in Marine Biology laboratory Annamalai University at Parangipettai.
\end{abstract}

\section{INTRODUCTION}

The quality of water in any ecosystem provides vital information regarding the obtainable resources for supporting life in that system [1]. All well-known life forms on earth depend on water. Hence, hydrological studies are a vital to know the connection between its tropic levels and webs [2]. The physical condition of an aquatic environment depends on the physico- chemical and biological characteristics and will facilitate in their conservation and organization, [3].Water is single amongst the foremost necessary and abundant compounds of the environment. Each living organism in the world needs water for their continued existence and development of body.

In the period of water quality parameter analysis some changes are observed on the tested water. Parameters that may be tested include ammonia, nitrite, nitrate, dissolved oxygen, temperature, salinity \%o (ppt-parts per thousand) and $\mathrm{pH}$. An assessment of the marine can also present an indication of water quality. several reports were estimated and mentioned the changes in the quality of the water on the physico-chemical features of Indian estuaries $[4,5,6,7,8,9,10,11,12,13,14]$. During the period of from July 2013 to June 2014 we investigated ammonia, nitrite, nitrate, dissolved oxygen, temperature, salinity and $\mathrm{pH}$. The concentration and seven physicochemical parameters value marine water samples in the presence of water. 


\section{EXPERIMENTAL}

\subsection{Sample area and Sample collection}

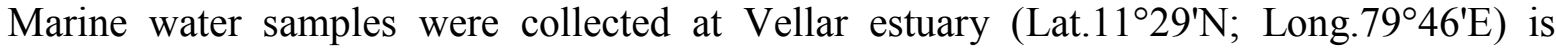
located near Parangipettai on the southeast coast of India and UV filtered Marine water samples in presence of water from CAS in marine biology laboratory Annamalai University at Parangipettai.

\subsection{Sample Analysis}

a. Determination of Ammonia, Nitrite, Nitrate, Dissolved oxygen, Temperature, Salinity, pH in the Water Samples

The concentration of ammonia, nitrate and nitrite were determined using Dr. Lange Cadas (100 UV Visible Spectrophotometer). Ammonia was determined using direct Nesslerzation method [15]. Nitrate was determined using Phenol disulfonic acid method [16] while nitrite was determined using diazo method [17]. Dissolved oxygen was determined using through by Winkler's method, Temperature be determined using digital equipments, Salinity was determined using standard methods, and $\mathrm{pH}$ was determined using $\mathrm{pH}$ meter.

\section{b. Determination of Physicochemical Parameters}

Physicochemical parameters of the samples were determined by using standard procedures $[18,19,20,21,22]$. The physico-chemical parameters of water be analyzed on monthly bases for a period of one year from July 2013 to June 2014. The parameters like ammonia, nitrite, nitrate, dissolved oxygen, temperature, salinity and $\mathrm{pH}$.

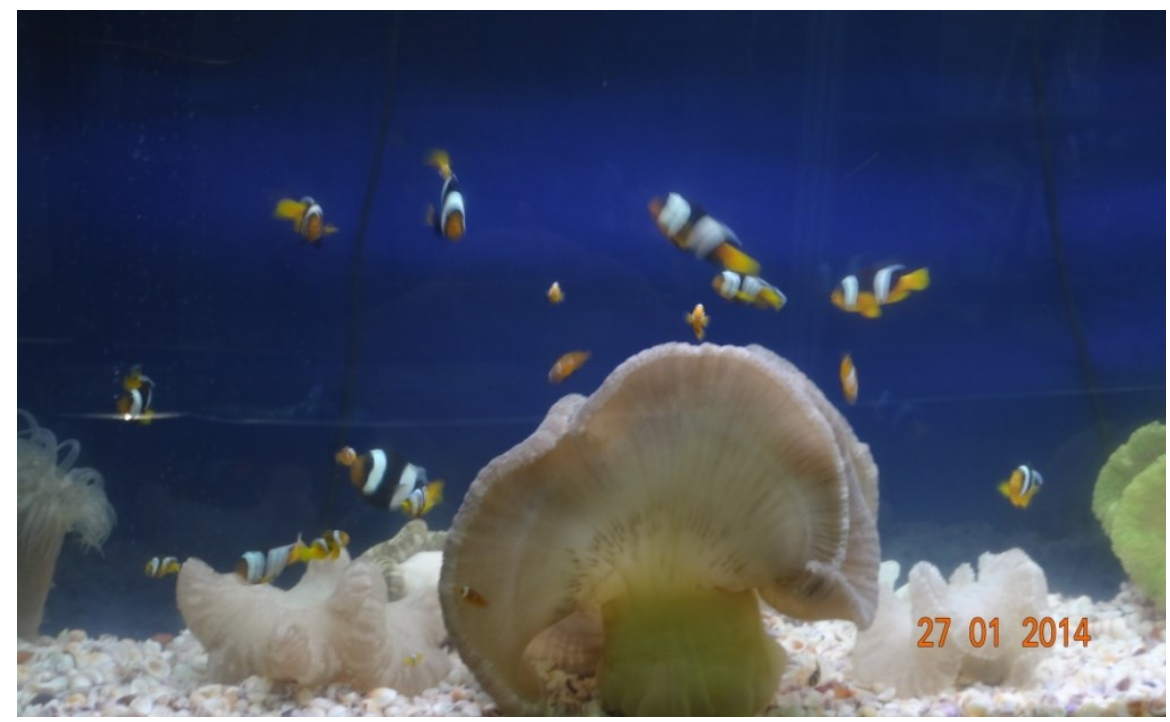

Fig 1: Amphiprion sebae with Sea anemone in cultured tank conditions

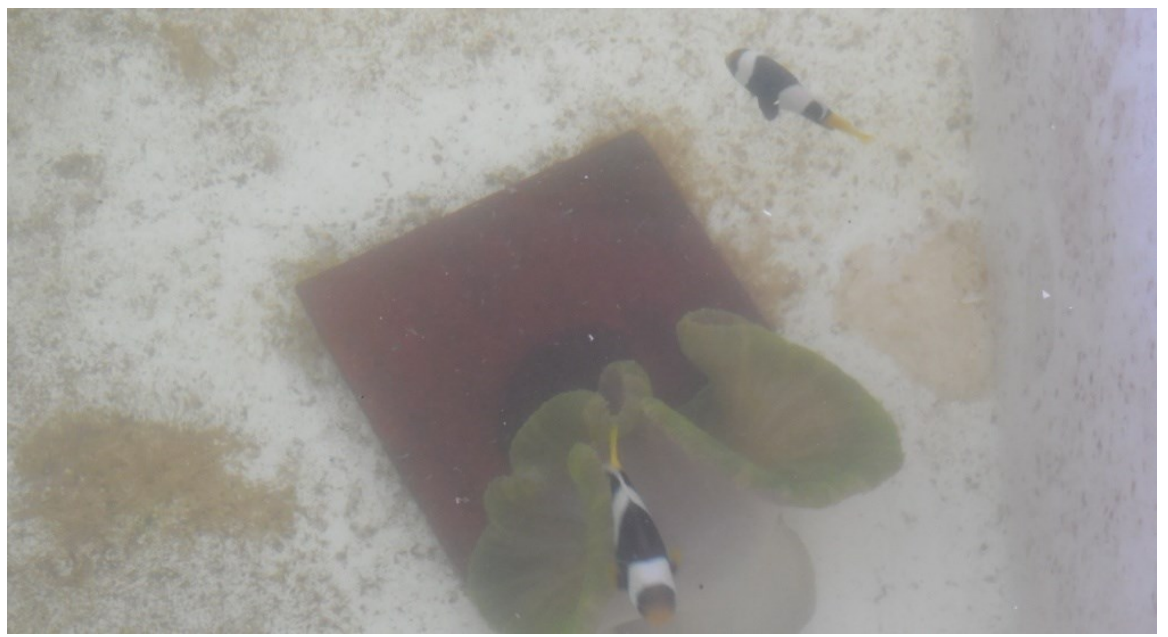

Fig 2: Amphiprion sebae with Sea anemone in cultured tank conditions 


\section{RESULTS}

\section{Concentration of Ammonia, Nitrite, Nitrate, Dissolved oxygen, Temperature, Salinity and pH in the Samples}

\section{Ammonia}

Ammonia is generally present in water, still in very small amount, as a result of microbiological activity which causes the reduction of nitrogen-containing compounds. When present in maximum level above $1.158 \mathrm{~mol}^{-} 1$, it is measured spectroscopically at $425 \mathrm{~nm}$ radiation by making a color complex with Nessler's reagent. The environment of reaction is alkaline and cause severe meddling from hardness in water.

\section{Nitrite}

Nitrite is another form of nitrogenous waste product found in water. Typical concentrations of nitrite- $\mathrm{N}$ in marine water range from 0.811 to $0.922 \mu \mathrm{mol}^{-} 1$. During the process of nitrification, microorganisms can transform ammonia into nitrite and nitrite into nitrate. In worth full marine ornamental fish, nitrite levels can enhance very much. The toxicity of nitrite to fish varies greatly with the species of fish. Further more information on nitrite in fish tank. As with ammonia, nitrite levels in surface water samples may change during consignment to the laboratory. Icing samples will help stabilize the nitrite levels. High levels measured in water samples should be addressed in discussion with a fisheries or aquaculture specialist.

\section{Nitrate}

Nitrate levels in marine water for farm animals are a major concern. The concentrations of nitrate- $\mathrm{N}$ in marine water range maximum level above $4.84 \mu \mathrm{mol}^{-} 1$ in marine water for fish utilization.

\section{Dissolved oxygen}

DO is one of the most main parameter. Its correlation with water body gives direct and indirect information e.g. bacterial activity, photosynthesis, availability of nutrients, stratification etc. [23]. In the progress of summer, dissolved oxygen decreased due to increase in temperature and also due to increased microbial activity $[24,25,26,27]$. The high DO in summer is due to increase in temperature and duration of bright sunlight has influence on the $\%$ of soluble gases $\left(\mathrm{O}^{2} \& \mathrm{CO}^{2}\right)$. During summer the long days and intense sunlight seem to accelerate photosynthesis by phytoplankton, utilizing $\mathrm{CO} 2$ and giving off oxygen. This possibly accounts for the greater qualities of $\mathrm{O} 2$ recorded during summer [28]. This procedure needs special BOD bottles which seal the inside environment from atmospheric oxygen. The concentration of dissolved oxygen can be readily, and accurately, measured by the method originally developed by Winkler in 1888 (Ber. Deutsch Chem. Gos., 21, 2843). Dissolved oxygen can also be determined with precision using oxygen sensitive electrodes; such electrodes require frequent standardization with waters containing known concentrations of oxygen. The concentrations dissolved oxygen in marine water maximum level above $2.4 \mathrm{mg}^{-} 1$.

\section{Temperature}

Temperature mercury filled centigrade thermometers calibrate from 32.3 to $100{ }^{\circ} \mathrm{C}$ is used for temperature dimensions. In an established system the water temperature controls the rate of all chemical reactions, and affects fish growth, reproduction and resistance. Severe hotness changes can be lethal to fish.

\section{Salinity}

Salinity has been viewed as one of the most important variables influencing the utilization of organisms in estuaries [29]. Spotted grunters are euryhaline and have been found to tolerate salinities from 0 to 90 [30].In this study, marine water was in extensive range of salinities (ranging from 0 to $36 \mathrm{ppt}$ ). The variation in the mean salinity between the first and second periods can be ascribed to the large proportion of fish located in the freshwater upper reaches of the estuary during the initial stages of the second period. 


\section{7. pH}

$\mathrm{pH}$ is the negative logarithm of the hydrogen ion concentration of a solution and it is thus a measure of whether the liquid is acid or alkaline. The range of natural $\mathrm{pH}$ in fresh waters extends from around 4.5, for acid, peaty upland waters, to over 10.0 in waters where there is intense photosynthetic activity by algae. However, the most frequently encountered range is 6.5-8.0.The $\mathrm{pH}$ is determined by digital $\mathrm{pH}$ meter which gives direct values of $\mathrm{pH}$. Lower the $\mathrm{pH}$ value higher is the corrosive nature of water. $\mathrm{pH}$ was positively correlated with electrical conductance and total alkalinity [31].

Table 1: Cultured water sample analysis of marine ornamental fish during period of July 2013 to June 2014.

\begin{tabular}{|c|c|c|c|c|c|c|c|c|c|c|c|c|c|c|c|}
\hline Parameter & July & Aug & Sep & Oet & Nov & Dec & Jan & Feb & Mar & Apr & May & Jun & Max & Min & Ave \\
\hline $\begin{array}{c}\text { Ammonia } \\
\left(\mu \mathrm{mol}^{-} 1\right)\end{array}$ & 0.302 & 0.033 & 0.022 & 0.041 & 0.042 & 0.036 & 0.064 & 0.075 & 0.047 & 0.338 & 0.080 & 0.078 & 1.158 & 0.022 & 0.178 \\
\hline $\begin{array}{c}\text { Nitrite } \\
\left(\mu \mathrm{mol}^{-1} 1\right)\end{array}$ & 0.382 & 0.401 & 0.383 & 0.041 & 0.336 & 0.392 & 0.616 & 0.280 & 0.623 & 0.811 & 0.922 & 0.442 & 0.922 & 0.041 & 0.469 \\
\hline $\begin{array}{c}\text { Nitrate } \\
\left(\mu \mathrm{mol}^{-1)}\right)\end{array}$ & 1.56 & 1.43 & 2.9 & 0.247 & 2.26 & 1.92 & 1.96 & 1.83 & 2.8 & 2.0 & 3.0 & 4.84 & 4.84 & 0.247 & 2.228 \\
\hline $\begin{array}{c}\text { Dissolved } \\
\text { oxygen } \\
(m g 1)\end{array}$ & 1.25 & 1.28 & 2.40 & 1.51 & 1.86 & 2.2 & 2.0 & 1.8 & 1.6 & 1.8 & 1.7 & 1.8 & 2.4 & 1.25 & 1.775 \\
\hline $\begin{array}{c}\text { Temperature } \\
(\mathrm{oC})\end{array}$ & 28 & 28.5 & 29 & 26.5 & 28.5 & 30 & 29.5 & 29 & 30 & 30 & 32.3 & 31 & 32.3 & 26.5 & 29.36 \\
\hline $\begin{array}{c}\text { Salinity } \% \\
\text { (ppt) }\end{array}$ & 23 & 33 & 30 & 28 & 29 & 32 & 30 & 32 & 34 & 33 & 34 & 32 & 34 & 23 & 30.5 \\
\hline $\mathrm{pH}$ & 8.0 & 7.0 & 8.2 & 7.3 & 7.8 & 8.0 & 7.5 & 7.0 & 8.0 & 8.0 & 8.2 & 7.9 & 8.2 & 7 & 7.721 \\
\hline \multicolumn{13}{|c|}{ Total value Sum (One year data) } & 83.82 & 58.06 & 72.231 \\
\hline \multicolumn{13}{|c|}{ Total Maximum value } & 83.82 & 58.06 & 7.2 .231 \\
\hline \multicolumn{13}{|c|}{ Total Minimum value } & 0.922 & 0.022 & 0.178 \\
\hline \multicolumn{13}{|c|}{ Total Average value } & 25.23 & 17.42 & 21.687 \\
\hline
\end{tabular}

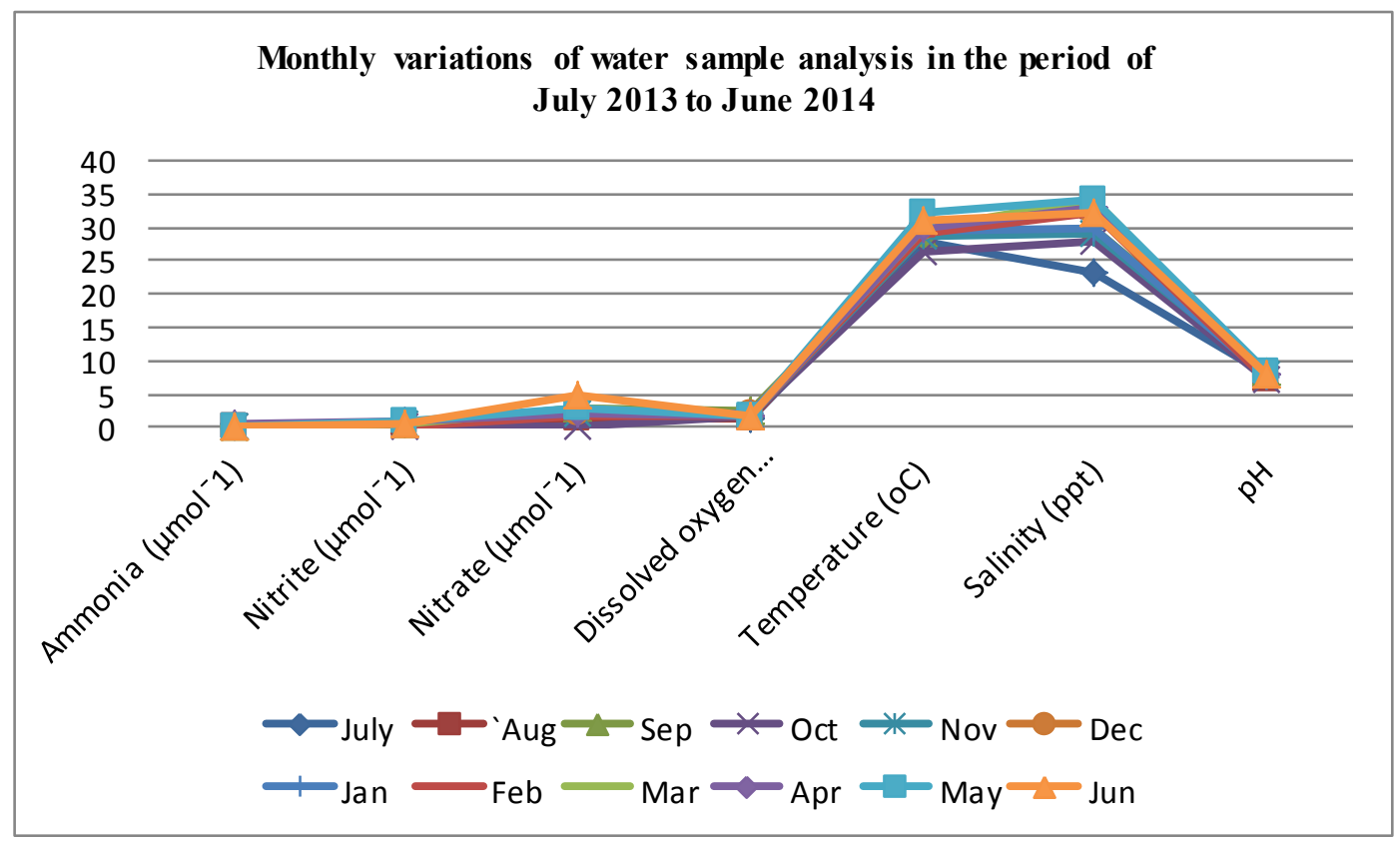

Fig 3: Monthly variations of water sample analysis in the period of July 2013 to June 2014.

\section{DISCUSSION}

\section{Ammonia}

Ammonia is generally present in waters, still in very small amounts, as a result of microbiological activity which causes the reduction of nitrogen-containing compounds. When present in maximum level above $1.158 \mathrm{mmol}^{-} 1$, it is measured spectroscopically at $425 \mathrm{~nm}$ radiation by making a color complex with Nessler's reagent. The environment of reaction is alkaline and cause severe meddling from hardness in water. 


\section{Nitrite}

Nitrite is another form of nitrogenous waste product found in water. Typical concentrations of nitrite- $\mathrm{N}$ in marine water range from 0.811 to $0.922 \mu \mathrm{mol}^{-} 1$. Through the process of nitrification, microorganisms can transform ammonia into nitrite and nitrite into nitrate. In worth full marine ornamental fish, nitrite levels can increase greatly. The toxicity of nitrite to fish varies greatly with the species of fish. Further more information on nitrite in fish tank. As with ammonia, nitrite levels in surface water samples may change during consignment to the laboratory. Icing samples will help stabilize the nitrite levels. High levels measured in water samples should be addressed in discussion with a fisheries or aquaculture specialist.

\section{Nitrate}

Nitrate levels in marine water for farm animals are a major concern. The concentrations of nitrate- $\mathrm{N}$ in marine water range maximum level above $4.84 \mu \mathrm{mol}^{-} 1$ in marine water for fish consumption.

\section{Dissolved oxygen}

DO is one of the most main parameter. Its correlation with water body gives direct and indirect information e.g. bacterial activity, photosynthesis, availability of nutrients, stratification etc. [23]. In the progress of summer, dissolved oxygen decreased due to increase in temperature and also due to increased microbial activity [24,25,26,27]. The high DO in summer is due to increase in temperature and duration of bright sunlight has influence on the $\%$ of soluble gases $\left(\mathrm{O}^{2} \& \mathrm{CO}^{2}\right)$. During summer the long days and intense sunlight seem to accelerate photosynthesis by phytoplankton, utilizing $\mathrm{CO}_{2}$ and giving off oxygen. This possibly accounts for the greater qualities of $\mathrm{O}_{2}$ recorded during summer [28]. This procedure needs special BOD bottles which seal the inside environment from atmospheric oxygen. The concentration of dissolved oxygen can be readily, and accurately, measured by the method originally developed by Winkler in 1888 (Ber. Deutsch Chem. Gos., 21, 2843). Dissolved oxygen can also be determined with precision using oxygen sensitive electrodes; such electrodes require frequent standardization with waters containing known concentrations of oxygen. The concentrations dissolved oxygen in marine water maximum level above $2.4 \mathrm{mg}^{-} 1$.

\section{Temperature}

Temperature a mercury filled centigrade thermometer calibrated from 32.3 to $100{ }^{\circ} \mathrm{C}$ is used for temperature dimensions. In an established system the water temperature controls the rate of all chemical reactions, and affects fish growth, reproduction and resistance. Severe hotness changes can be lethal to fish.

\section{Salinity}

Salinity has been viewed as one of the most important variables influencing the utilization of organisms in estuaries [29]. Spotted grunters are euryhaline and have been found to tolerate salinities from 0 to 90 [30]. In this study, marine water was in extensive range of salinities (ranging from 0 to $36 \mathrm{ppt}$ ). The variation in the mean salinity between the first and second periods can be ascribed to the large proportion of fish located in the freshwater upper reaches of the estuary during the initial stages of the second period.

\section{7. $\mathrm{pH}$}

$\mathrm{pH}$ is the negative logarithm of the hydrogen ion concentration of a solution and it is thus a measure of whether the liquid is acid or alkaline. The range of natural $\mathrm{pH}$ in fresh waters extends from around 4.5, for acid, peaty upland waters, to over 10.0 in waters where there is intense photosynthetic activity by algae. However, the most frequently encountered range is $6.5-8.0$.The $\mathrm{pH}$ is determined by digital $\mathrm{pH}$ meter which gives direct values of $\mathrm{pH}$. Lower the $\mathrm{pH}$ value higher is the corrosive nature of water. $\mathrm{pH}$ was positively correlated with electrical conductance and total alkalinity [31].

\section{CONCLUSION}

The present studies were concentration of ammonia, nitrite, nitrate, dissolved oxygen, temperature, salinity and $\mathrm{pH}$. For seven physicochemical parameters were determined in marine water samples along with marine ornamental fish water sources from CAS in marine biology laboratory conditions at Parangipettai. Water sample have been studied at a marine water sources. 
The study concentrations of parameters like ammonia, nitrite, nitrate, dissolved oxygen, temperature, salinity, and $\mathrm{pH}$. And physicochemical parameters have been calculated. The data showed the difference of the investigated parameters in samples as follows; Concentration of water quality parameters like ammonia was maximum level above $1.158 \mu \mathrm{mol}^{-} 1$, nitrite was ranging from 0.811 to $0.922 \mu \mathrm{mol}^{-} 1$, nitrate was range maximum level above $4.84 \mu \mathrm{mol}^{-} 1$, dissolved oxygen content was maximum level above $2.4 \mathrm{mg}^{-}$, temperature was ranging from 32.3 to $100{ }^{\circ} \mathrm{C}$, salinity values ranging from 0 to $36 \mathrm{ppt}$ and $\mathrm{pH}$ was ranging from 6.5 to 8.0.

\section{References}

[1] Medudhula Thirupathaiah, Samatha C.h, Chintha Sammaiah., Int J of Env Sciences., 3(1): (2012).

[2] Govindasamy C, Arulpriya M, Ruban P, Meenakshi V.R., J. Trop. Life Sci., 2 (1): (2013) 1-5.

[3] Venkatesharaju K, Ravikumar P, Somashekhar R.K, Prakash K. L., J. Sci. Engineering and tech. 6(1): (2010) 50-59.

[4] Govindasamy C, Kannan L, Jayapaul Azariah., J. Environ. Biol., 21 :(2000) 1-7.

[5] Rajasegar M., J. Environ. Biol., 24: (2003) 95-101.

[6] Balasubramanian R, Kannan L., Int. J. Ecol. Environ. Sci., 31: (2005) 265-271.

[7] Paramasivam S, Kannan L., Int. J. Ecol. Environ. Sci., 31: (2005) 273-278.

[8] Rajaram R, Srinivasan M, Rajasegar M., J. Environ. Biol., 26: (2005) 291-297.

[9] Ajithkumar T.T, Thangaradjou T, Kannan L., J. Mar. Biol. Ass. India, 48: (2006) 131-138.

[10] Asha P.S, Diwakar, J. Mar. Biol. Ass. India, 49: (2007) 7-11.

[11] Ashok prabu V, Perumal P, Rajkumar M., J. Mar. Biol. Ass. India, 47: (2005) 14-19.

[12] Saravanakumar A, Rajkumar M, Thivakaran G.A, Sesh Serebiah J., J. Environ. Biol., 29: (2008) 271-274.

[13] Gowda S.J, Radika M.P, Kadoo N.Y, Mhase L.B, Gupta V.S., Mol. Breed., 24 : (2009) 177183.

[14] Vengadesh P.N, Rajkumar M, Perumal P, Thillai Rajasekar K., J. Environ. Biol., 30: (2009) 1035-1046.

[15] Boutwell Jr., Clinical Chemistry, 3: (1957) 4205-4216.

[16] Hora F.D, Webber P.J., Analyst, 85: (1960) 567-569.

[17] Kumar B.S.M, Srikanth T.R, Balasubramanian N., Fresenius J. Anal. Chem., 345(8-9): (1993) 592-594.

[18] Rani F.H, Thatcher L.L., U.S Govt. Office, Washington, USA., (1992).

[19] APHA., $18^{\text {th }}$ edition, USA. J. H. (1992).

[20] Pelezar M.J, Reid R.D, Chem E.C.S, Kreig N.R., Microbiology $5^{\text {th }}$ edition, Mc-Graw Hill Publication, New Delhi,(1986).

[21] Jain, Jain., $15^{\text {th }}$ edition, Dhanapat Rai Publishing Company, New Delhi, (2007).

[22]Jayalakshmi V, Lakshmi N, Charya M.A.S., International Journal of Research in Pharmaceutical and Biomedical Sciences, 2: (2011)1041-1046.

[23]Premlata Vikal., Biological Forum, Biological Forum- An International Journal, 1(2): (2009) 97-102. 
[24] Moss B., Fresh Water Biology, 2 (1972) 309-320.

[25] Morrissette D.G, Mavinic D.S., Journal of Environment: Engg. Division, EP, 6: (1978) 12131222.

[26] Sangu R.P.S, Sharma S.K., Ind. J. Ecol 14(20): (1987) 278-287.

[27] Kataria H.C, Quershi H.A, Iqbal S.A, Shandilya A.K., Pollution Research. 15(2): (1996) 191193.

[28] Krishnamurthy R., India, Journal of Environmental Biology, 11(3): (1990) 335-343.

[29] Marshall S, Elliott M., Original Research Article Estuarine, Coastal and Shelf Science, (1998) $175-184$

[30] Whitfield A.K, Blaber S.J.M, Cyrus D.P., South Afr. J. Zool., 16: (1981) 151-155.

[31] Guptaa D.P, Sunitaa J.P, Saharan, Researcher, 1(2): 2009. 